\title{
MANAJEMEN DIRI GURU RAUDHATUL ATHFAL (RA) BERPRESTASI DI YOGYAKARTA
}

\author{
Fu'ad Arif Noor \\ STPI Bina Insan Mulia Yogyakarta \\ pgmi.stpibimjogja@gmail.com
}

\begin{abstract}
Abstrak
Penelitian ini dilakukan untuk mengetahui manajemen diri guru RA berprestasi di Yogyakarta yang mampu menjadi teladan. Metode penelitian kualitatif dengan pendekatan psikologis yang dilakukan langsung kepada objek yang diteliti, guna memperoleh semua data yang berkaitan dengan manajemen diri guru RA berprestasi. Teknik analisis mereduksi data, menyajikan, menarik kesimpulan dan menverifikasi data. Pengumpulan data menggunakan wawancara, dokumentasi, dan observasi, serta uji keabsahan data dengan kredibilitas triangulasi. Hasil penelitian mengungkapkan bahwa: manajemen diri guru RA berprestasi di Yogyakarta berprinsip meningkat secara efisien, efektif dalam produktivitas kerja, dan berfungsi untuk menumbuhkan karakter dan kompetensi diri berubah lebih baik dan menjadi pembiasaan diri dalam rutinitas keseharian, serta pengaruh pengembangan diri terhadap kinerja guru RA berprestasi di Yogyakarta mampu memberikan kekuatan dan menghasilkan etos kerja yang disebut dengan kerja keras, dan kerja cerdas, serta kerja ikhlas yang bisa menumbuhkan perilaku positif, produktif, maupun kontributif.
\end{abstract}

Kata kunci: Manajemen diri, guru RA, berprestasi, Yogyakarta.

\begin{abstract}
This study was conducted to determine the self-management of outstanding $R A$ teachers in Yogyakarta who are able to be role models. Qualitative research methods with psychological approaches are carried out directly to the object under study, in order to obtain all data relating to the self-management of high achieving $R A$ teachers. Analysis techniques reduce data, present, draw conclusions and verify data. Data collection uses interviews, documentation, and observation, and tests the validity of the data with triangulation credibility. The results revealed that: selfmanagement of outstanding RA teachers in Yogyakarta principally increased efficiently, were effective in work productivity, and functioned to foster selfcharacter and competence to change better and become habituated to daily routines, as well as the influence of self-development on the performance of outstanding RA teachers in Yogyakarta is able to provide strength and produce a work ethic called hard work, and smart work, and sincere work that can foster positive, productive, and contributive behavior.
\end{abstract}

Keywords: Self management, RA teacher, achievers, Yogyakarta. 


\section{A. Pendahuluan}

Setiap orang memiliki cita-cita yang berbeda-beda, cita-cita hidup yang berlainan, sebab setiap orang memiliki keinginan dan pemikiran yang berlainan pula. Meraih cita-cita tersebut, diperlukan rencana untuk pengelolaan diri yang baik, tanpa pengelolaan diri yang baik, cita-cita tersebut sulit untuk tercapai (wawancara dengan Sri Ngadiyati, 2018). Pengelolaan diri yang baik tersebut disebut manajemen diri. Dalam bab ini menjelaskan perihal jawaban tentang manajemen diri guru RA berprestasi di Yogyakarta yang terdiri dari prinsipprinsipnya, fungsi manajemen diri, pengaruhnya terhadap kinerja, dan berbagai faktor yang memengaruhi, serta aspek-aspek manajemen diri guru RA berprestasi tersebut.

Guru RA berprestasi mengajarkan kepada peserta didik bagaimana mengorganisasikan sesuatu hal (mengatur sesuatu), membuat daftar prioritas, melatihkan bagaimana berkomunikasi secara aktif maupun efektif, menginterpretasikan informasi, mengecek kesahihan informasi tersebut seperti fakta atau opini, membuat rencana jangka panjang untuk memperoleh suatu tujuan, memperhitungkan resiko dan akibat suatu tindakan, memecahkan berbagai permasalahan secara kreatif, serta melakukan inovasi.

Berbagai hal yang bisa dikerjakan guru untuk melaksanakannya seperti kegiatan berlatih bagaimana menstabilkan emosi yang secara impulsif seringkali muncul, mengajarkan bagaimana membuat perencanaan suatu hal yang bisa dikaitkan dengan materi kegiatan pembelajaran, memberikan respon terhadap suatu hal dengan bijak dan tepat, belajar dari kesalahan atau pelanggaran yang dilakukan terhadap aturan-aturan sekolah atau aturan-aturan kelas, belajar duduk dengan tenang dan tidak membuat kegaduhan di kelas, berpikir dengan mendalam sebelum mengambil keputusan ataupun melakukan suatu tindakan. Mendidik siswa atau peserta didik dengan cara-cara demikian, antara lain akan dapat membantu mereka berkembang menjadi pribadi yang mempunyai daya pikir optimal serta memiliki stabilitas emosi positif. Guru RA berprestasi telah melakukan hal-hal tersebut sehingga kinerja dan perannya sebagai pendidik benar-benar berjalan untuk membangun insan yang cerdas, kreatif, dan mempunyai sosok pribadi yang santun dan lagi menyenangkan. 


\section{B. Pembahasan}

\section{Prinsip-prinsip Manajemen Diri Guru RA Berprestasi}

Prinsip manajemen diri guru RA berprestasi: "Prinsip saya melakukan apa yang sekarang bisa dilakukan, melakukan apa yang sudah menjadi tanggung jawab saya, melakukan sesuatu yang bermanfaat untuk bersama, belajar, dan belajar, serta terus belajar untuk mengembangkan lembaga (wawancara dengan Estri Ritah Indriwati, 2018). Demikian pula menurut ibu Sri Ngadiyati: Prinsip diri saya itu "Hidup untuk beribadah, hidup tidak boleh statis, tetapi harus bergerak untuk maju dan lebih baik" (wawancara dengan Sri Ngadiyati, 2018). Serta "berfungsi untuk kemajuan diri pribadi dan lembaga saya, menjaga eksistensi lembaga, serta untuk menambah ilmu bagi diri pribadi saya" (wawancara dengan Estri Ritah Indriwati, 2018).

Berbeda dengan yang diungkapkan ibu Rufiyati Ambar Ningrum, bahwa dia berprinsip "lakukan perbuatan baik selama masih ada kesempatan". Artinya di mana ada kesempatan untuk berbuat baik, mengembangkan diri, maka kesempatan tersebut sebaiknya segera diraih karena kesempatan yang sama tidak akan datang untuk kedua kalinya. Kalau ada kesempatan yang serupa pada waktu yang berbeda, sesungguhnya itu tidak sama dengan kesempatan sebelumnya, karena setiap pergantian waktu keadaan selalu berubah. Banyak hal yang akan didapat ketika kita mengambil kesempatan. Walaupun hasilnya kadang tidak sesuai harapan, tetapi pasti ada pelajaran yang boleh diambil untuk pengembangan diri agar menjadi lebih matang (wawancara dengan Ruwiyati Ambar Ningrum, 2018).

Anton Ariyadi dalam manajemen dirinya berprinsip bahwa: "Bekerja dan belajar dengan jujur, belajar dari pengalaman, tidak menunda pekerja" (wawancara dengan Anton Ariyadi, 2018). Berikutnya "Saya berprinsip senantiasa berusaha agar Anfa'uhum linnās, bermanfaat bagi sesama di sekitar lingkungan terutama tempat keberadaan di mana saya berada. Kemudian berlomba-lomba dalam kebaikan atau berpedoman pada fastabiqu al-khoirāt, hidup dinamis mengikuti zaman, berjuang terus menerus mencari ilmu untuk menambah wawasan, serta ikhlas dalam bertindak" (wawancara dengan Rina Wahyuni, 2018). 
Pentingnya berbagai prinsip dasar dalam penerapan manajemen, yaitu memilih metode kerja, penetapan pengembangan keahlian dan pekerjaan, pemilihan kriteria dan prosedur kerja, memastikan batasan-batasan tugas, membuat dan mempersiapkan spesifikasi tugas, melaksanakan pendidikan serta latihan, melaksanakan sistem dan kisaran imbalan itu diharapkan untuk berkembang efektivitas, efisiensi, serta produktivitas kerja (Nanang Fatah, 2000:12). Fayol, dalam hubungannya terhadap prinsip dasar manajemen, mengemukakan sejumlah prinsip manajemen, yaitu:

a. Pembagian kerja

Pekerjaan seseorang semakin menjadi spesialis, tentu pekerjaan yang dilakukannya juga semakin efisien. Alasan adanya pembagian kerja ini yaitu:

1) Setiap orang mempunyai kecerdasan yang berlainan atau berbedabeda;

2) Setiap jenis lapangan pekerjaan mempersiapkan tenaga ahli atau pegawai yang berbeda keahliannya;

3) setiap pekerja mempunyai pengalaman kerja atau keahlian yang berbeda;

4) Mentalitas perilaku pekerja berbeda;

5) Pemakaian waktu berbeda;

6) Latar belakang pekerjaan yang berbeda;

7) Tingkat jenjang pendidikan yang dimiliki berbeda (Kadarman dan Jusuf Udaya, 1995 : 32)

Agar prinsip ini berjalan dengan optimal, maka perlu dilakukan tes atau penilaian terhadap calon guru RA berprestasi. Misalnya berupa: psikotes, wawancara, dan lainnya. Dalam kompetisi guru RA berprestasi tahun 2017 komponen penilaian meliputi: dokumen berupa portofolio, karya tulis yang ilmiah, wawancara dan presentasi perihal pemahaman, penguasaan, dan wawasan seputar pengembangan potensi, bakat, dan prestasi dari peserta didik serta pengembangan masyarakat, kemampuan berbahasa Inggris dan atau Bahasa Arab, sampai mempunyai karya inovatif-kreatif (Dirjen Pendis, 2017 : 7-8). 
b. Otoritas dan tanggungjawab

Maksudnya adalah bahwa harus ada wewenang atau tanggungjawab yang diterapkan secara proporsional, agar pelaksanaan kegiatan dalam sebuah organisasi atau lembaga mampu berjalan dengan baik. Dalam konteks ini, seorang manajer yaitu individu yang memiliki wewenang dan bertanggungjawab. Oleh karenanya manajer atau pimpinan memberikan perintah maupun tugas agar supaya orang lain dapat bekerja maksimal (U. Saefulloh, 2014 : 11).

c. Disiplin

Prinsip ini menjadi implikasi dari sikap otoritas dan tanggung jawab atau kewajiban di atas. Setiap anggota organisasi, baik bawahan maupun atasan harus mematuhi dan menghormati peraturan-peraturan dalam organisasi yang telah diputuskan bersama (U. Saefullah, 2014:13)

d. Kesatuan perintah

Komando atau kesatuan perintah yaitu sebuah perintah yang berada di level kepala tertinggi kepada staf atau bawahannya (U. Saefullah, 2014 : 14). Setiap anggota harus melaksanakan perintah atau komando dari seorang saja, supaya tidak akan terjadi kekaburan otoritas dan konflik perintah.

e. Kesatuan arah

Meskipun dalam sebuah organisasi terdiri berbagai devisi atau bagian, namun seluruh pelaksanannya harus tertunpu pada satu arah tujuan yang sama. Untuk itu, pengarahan pencapaian organisasi diberikan oleh salah satu orang berdasarkan sebuah rencana.

f. Pengutamaan kepentingan (mașlahah) umum atau organisasi daripada individu.

Prinsip ini seperti konsep al-mașlahah al-`āmmah dalam kaidah fiqhnya, yaitu lebih mendahulukan kepentingan umum atau organisasi dalam setiap aktivitas atau kegiatan organisasi, daripada mementingkan kepentingan atau keperluan pribadinya.

g. Pemberian kontra prestasi atau remunerasi.

Prinsip ini dalam Islam dikenal dengan al-`ujrah biqadr almusyaqah, upah diukur oleh tingkat kesulitan pekerjaannya. Semakin tinggi jabatan, maka semakin penuh pula tanggungjawab atas kewajiaban 
yang diembannya. Oleh karena itu, tentu harus diberikan imbalan yang sebanding terhadap beban atau tanggungan kerja yang diembannya tersebut.

h. Sentralisasi/pemusatan

Prinsip ini didasarkan bahwa setiap organisasi pasti mempunyai pusat wewenang dan kekuasaan instruksi. Kemudian ia akan mendistribusikan wewenangnya kepada bawahannya. Meskipun demikian, tetap penanggungjawab utamanya terpusat pada manajer puncak dalam sebuah organisasi. Manajer yaitu penanggung jawab utama dan terakhir dari regulasi ketetapan yang diambilnya.

i. Hirarki

Otoritas wewenang dalam organisasi bergerak dari atas menuju ke bawah. Namun demikian, proses ini tidak boleh menyalahi kapasitas yang dimiliki bawahannya. Sehingga tidak salah kaprah, misalnya, desain produk ke bagian pemasaran, bagian akademik mengurusi keuangan. Oleh karenanya perlu adanya sistem pelimpahan wewenang dan tanggungjawab yang secara hirarkis tersusun dalam kapasitas yang sama. Misalnya dari desain produk ke bagian pembuatan, dari bagian akademik ke bagian kurikulum, dan seterusnya.

j. Teratur

Manusia dan material diletakkan pada tempat sekaligus waktu yang serasi. Artinya, harus ada keteraturan dan ketertiban yang berjalan baik secara material maupun secara sosial. Secara material, misalnya inventaris sebuah organisasi harus terkelola dengan teratur dan tertib. Sementara secara manusia atau sosial, misalnya penempatan karyawan atau staf harus sesuai dengan kecakapan yang dimilikinya.

k. Keadilan

Meskipun secara struktural terjadi perbedaan, namun demikian seorang manajer harus adil dan akrab dengan bawahannya. Artinya, bukan berarti keadilan di sini diartikan dengan sama rasa sama rata. Akan tetapi, harus ada berasas pada kuantifikasi. Misalnya, jika bersangkutan dengan upah, maka dasarnya adalah kedudukannya, bila berhubungan dengan bonus, maka yang diukur adalah prestasinya (U. Saefullah, 2014:16) 
1. Kestabilan staf

Prinsip ini, berhubungan dengan proses kesinambungan kinerja dalam organisasi. Pergiliran karyawan atau pekerja yang terlalu tinggi memperlihatkan tidak efisiennya fungsi suatu organisasi. Artinya, semakin sering berganti pejabat, maka semakin buruk dalam sebuah organisasi (U. Saefullah, 2014:17).

m. Inisiatif

Anggota diberikan kelonggaran untuk menjalankan dan menyusun program kerjanya. Setiap anggota harus didorong untuk mempunyai inisiatif sendiri dalam mengembangkan kinerjanya. Sehingga tidak tergantung pada atasannya.

n. Semangat kelompok

Prinsip ini bertolak dari kesamaan visi serta misi organisasi. Semua komponen dalam organisasi merupakan sistem terpadu. Seluruh karyawan atau staf organsiasi bagaikan jejaring laba-laba yang bersatu sebagai tim yang solid dalam memperjuangkan visi dan misi tersebut. Perihal tersebut mampu dilakukan dengan meningkatkan semangat kelompok, komunikasi yang aktif, dan melakukan wisata bersama.

\section{Fungsi Manajemen Diri Guru RA Berprestasi di Yogyakarta}

Fungsi manajemen diri menurut ibu Sri Ngadiyati, baginya yaitu "Pengembangan diri saya berfungsi untuk profesionalitas dalam bekerja dan berkarya, serta untuk sosialisasi dengan orang lain"(wawancara dengan Sri Ngadiyati, 2018). Senada dengan fungsi tersebut bahwa: "Pengembangan diri saya berfungsi untuk menumbuhkan karakter dan kompetensi diri berubah lebih baik dan menjadi pembiasaan dalam kehidupan sehari-hari" (wawancara dengan Anton Ariyadi,2018).

Fungsi Pengembangan diri saya dengan berusaha untuk selalu membantu orang lain khususnya kepada peserta didik sesuai kemampuan saya, dengan profesi saya sebagai guru RA, dengan berdasarkan hadīs̀ dan ayat al-Qur'ān sehingga bisa meningkatkan semangat yang menggebu-gebu bagi saya. Serta untuk meningkatkan kemampuan diri berpikir positif dan berusaha semaksimal mungkin dengan sekuat usaha maupun pikiran tersebut untuk mewujudkan impian dan keinginan saya (wawancara dengan Rina Wahyuni, 2018). 
Fungsi adalah besaran yang berkaitan, bila besaran yang satu berubah, maka besaran yang lain berubah (KBBI, 2006 : 245). Menurut sudut ilmu sosial yang dimaksud fungsi adalah adanya karakteristik atau perilaku tertentu yang menyeleksi suatu tugas tertentu dengan tugas lain, sehingga fungsi dan peran satu pekerjaan akan menggambarkan warna tersendiri sebagai persyaratan proses penyediaan prasarana dan sarana yang dibutuhkan untuk menyempurnakan aktivitas tersebut (Soebagio Atmodiwirio, 2001 : 1213) Jadi fungsi adalah tugas pokok yang harus dilaksanakan untuk menyelesaikan kegiatan. Dalam manjemen yang dimaksud fungsi adalah sebuah tugas tertentu yang harus dikerjakan sendiri (Sondang P Siagian, 2014 : 101).

Made Pidarta menguraikan fungsi manajemen dengan berbagai ragamnya terdiri:, merencanakan, mengorganisasikan, mengarahkan, menyusun staf, mengkoordinasi dan mengontrol, melaporkan dan mencatat, serta menyusun anggaran belanja. Berikutnya dibuat lebih sedehana yang meliputi: merencanakan, kemudian mengorganisasikan, mengkoordinasi, memberi komando, dan mengontrol (Made Pidarta, 2011 : 4).

Sementara Hani Handoko menjelaskan bahwa fungsi manjemen yang paling penting itu ada lima, yaitu: planning, kemudian organizing, staffing, lalu leading, dan controlling (T Hani Handoko, 2012 : 23). Selanjutnya Winardi menyatakan bahwa beberapa fungsi dasar manajemen di antaranya mencakup: perencanaan atau planning, kemudian pengorganisasian (organizing), dan pergerakkan (actuating), serta pengawasan (controlling) (Winardi, 2000 : 63). Sedangkan George R Terry menjelaskan, bahwa fungsi manajemen itu berupa: planning, kemudian organizing, dan actuating serta controlling (M.Manullang, 2005:19). Teori ini digunakan untuk memperjelas keterangan dari penulis yang akan disusun sebagai berikut:

\section{a. Planning (Perencanaan) Diri Guru RA Berprestasi}

Pada dasarnya perencanaan diri terjadi disetiap tipe kegiatan. Perencanaan diri yaitu proses dasar menentukan tujuan dan cara meraih keinginan dirinya. Perencanaan dalam organisasi esensial sekali, sebab dalam kenyataannya perencanaan mengambil peranan lebih dibanding dengan fungsi manajemen lainnya. 
Perencanaan diri bagi guru RA berprestasi yang disiapkan oleh Anton Ariyadi sesuai dengan pernyataannya sebagai berikut:

"Awalnya mempelajari juknis terlebih dahulu sampai bener-benar memahami point-pointnya, untuk fortofolionya saya mencatat dan mencari dokumen sesuai yang dibutuhkan, kemudian saya kumpulkan. Setelah saya merasa yakin cukup dengan fortofolionya, saya baru beralih membuat karya ilmiah. Kerena saya pernah juara lomba guru sains dan di kurikulum sekolah juga ada pembelajaran sains di setiap tema, maka karya ilmiah saya ambil sains. Kegiatan sains sudah dilakukan per tema jadi saya tinggal mengumpulkan dokumentasi, saya ulang lagi beberapa eksperimennya dan mengamati respon anak-anak yang sesuai dengan 6 aspek kompetensi perkembangan peserta didik".(wawancara dengan Anton Ariyadi, 2018)

Planning atau perencanaan diri adalah menghubung-hubungkan dan memilih kenyataan yang dihayalkan serta merumuskan berbagai langkah yang perlu untuk mendapatkan hasil yang diinginkan. Planning (perencanaan) diri sebagai formulasi tindakan masa mendatang difokuskan kepada tujuan yang hendak diraih oleh guru berprestasi (Zaini Muchtarom,1997:38). Lebih lengkap dari penjelasan tersebut Beishline menguraikan bahwa fungsi perencanaan itu menaruh jawaban terhadap beragam pertanyaan perihal apa, kemudian siapa, di mana, apabila, bagaimana, dan mengapa. Tegasnya sebagaimana diungkapkan bahwa: Perencanaan menentukan apa yang seharus diraih (penetapan waktu secara kuantitatif) dan jika hal itu hendak dicapai, maka hal itu harus diraih dengan siapa yang berkewajiban, dan mengapa hal tersebut harus diperoleh (M Manullang, 2005 : 48).

Selain itu, planning diri juga dapat berarti sebagai keseluruhan proses penentuan dan pemikiran secara matang dari berbagai hal yang hendak dilakukan di masa mendatang dalam rangka menciptakan tujuan diri yang ditetapkan (T Hani Handoko, 2012 : 108). Perencanaan (planning) diri merupakan sesuatu aktivitas yang hendak diraih dengan proses dan cara, serta suatu orientasi masa mendatang, pengambilan keputusan, kemudian rumusan beragam masalah secara formal dan jelas (Soebijanto Wirojoedo, 1985 : 6). Seseorang sebelum bisa mengorganisasikan, mengawasi atau mengarahkan, mereka harus 
menyusun rencana-rencana yang menyampaikan arah dan tujuan organisasi, dalam perencanaan memutuskan berbagai hal apa yang akan diputuskan, bagaimana melakukannya, kapan serta siapa yang melakukannya.

Jadi perencanaan diri adalah memilih kegiatan serta menetapkan perihal yang hendak dikerjakan. Perencanaan yang baik mampu diraih dengan mempertimbangkan situasi serta kondisi di waktu mendatang, kegiatan dan perencanaan yang ditetapkan tersebut akan dilaksanakan, pada periode saat ini maupun waktu rencana tersebut dibuat. Dari pengertian tersebut, bisa dijelaskan bahwa perencanaan menjadikan suatu proses yang menyiapkan seperangkat alternatif bagi program masa depan yang diarahakan kepada perolehan tujuan dengan upaya yang maksimal atau optimal dan mempertimbangkan berbagai kenyataan hasil yang nyata di aspek sosial, ekonomi, budaya secara menyeluruh bagi diri guru RA berprestasi.

b. Organizing Diri Guru RA Berprestasi

Pengorganisasian diri menjadi fungsi organik manajemen atau administrasi. Keutuhan proses pengelompokkan banyak orang, tugastugas, alat-alat, wewenang dan kewajiaban sedemikian rupa akhirnya tercipta suatu individu diri yang bisa digerakkan sebagai kesatuan terpadu dalam rangka meraih tujuan yang ditetapkan (Sodang P.Siagian, 2014 : 116). Untuk memahami hakikat diri sendiri, perlu diberi pengertian tentang organisasi diri. Perihal organisasi diri ini bisa diartikan sebagai setiap bentuk persatuan antara beberapa orang bahkan lebih bekerjasama untuk sesuatu tujuan bersama serta terikat dengan formal dalam persatuan yang selalu ada hubungan atau kaitannya antara sekelompok orang atau diri seorang yang dinamakan ketua atau pimpinan atau sekelompok orang lain dengan seorang yang dinamakan bawahan.

Mengorganisasikan merupakan proses mengatur mendistribusikan pekerjaan, sumber daya antar pekerja atau anggota organisasi, wewenang, sehingga mereka bisa mencapai sasaran organisasi (James A.F.Stoner, 1996 : 11). Pengorganisasian yaitu tindakan mengupayakan 
hubungan perbuatan yang efektif di antara beberapa orang, hingga mereka bisa bekerja sama dengan efisien serta memperoleh kepuasan individu dalam hal menjalankan berbagai tugas khusus dalam keadaan lingkungan tertentu guna meraih sasaran atau tujuan tertentu (Winardi, $2000: 217)$.

Organisasi diri berfungsi sebagai prasarana atau alat dari manajemen diri guna meraih tujuan yang ditetapkan, maka terhadap organisasi dapat diadakan peninjauan dari dua aspek. Pertama aspek organisasi sebagai wadah daripada sekelompok individu yang bekerja sama, dan aspek yang kedua organisasi sebagai proses dari penglompokan manusia dalam satu kerja yang efisien (F.X.Soedjadi, 1995 : 17). Menurut Nanang Fattah proses memilah kerja kedalam beragam pekerjaan yang lebih kecil, melimpahkan pekerjan-pekerjaan itu kepada orang yang sesuai kemampuannya (Nanang Fattah, 2000 : 71). Dengan demikian pengorganisasian bisa berarti sebuah proses dimana pekerjaan yang akan diberikan dalam beberapa komponen yang mampu ditangani, dan aktivitas mengkoordinasi berbagai hasil yang dicapai guna meraih tujuan tertentu (Winardi, $2000: 375$ ).

Dalam buku lain dijelaskan, organizing (pengorganisasian) diri sebagai upaya untuk mempertimbangkan tentang susunan organisasi diri, pembagian tugas, pembagian tanggung jawab, dan berbagai hal yang apabila dilakukan dengan seksama akan menjamin efesien penggunaan kinerja diri (Zaeni Muchtarom, 1997 : 38-39).

Pengorganisasian diri bagi guru RA berprestasi yang dilakukan oleh Anton Ariyadi dalam pernyataannya sebagai berikut:

"Sesudah data terkumpul baru saya susun laporan dan membuat power pointnya, ketika tampil presentasi saya mencoba menggunakan bahasa inggris, selain ingin menambah nilai karena dari segi fortofolio saya kurang maksimal, maka saya coba cari nilai lebih pada presentasinya. Selain itu tujuan lain, adalah mencoba melihat kemampuan dan menambah pengalaman saya saat presentasi dengan bahasa Inggris" (wawancara dengan Aton Ariyadi, 2018). 
c. Actuating atau Motivating (menggerakkan) Diri Guru RA Berprestasi

Bahwa keberhasilan suatu individu dalam mencapai tujuannya lebih banyak ditentukan oleh penguasaan diri. Pemimpin yang berhasil yaitu mereka yang sadar dan paham akan kekuatan dirinya yang paling relevan dengan perilakunya pada saat tertentu. Dia benar-benar memahami dirinya sendiri sebagai individu, dan kelompok, serta lingkungan sosial dimana mereka berada. Kemampuan untuk memotivasi atau mendorong, mengarahkan, mempengaruhi, dan berkomunikasi atau berinteraksi dengan bawahannya atau sekaligus pada dirinya sendiri yang hendak menetapkan efektifitas kinerja. Ini berhubungan dengan teknik bagaimana mampu memotivasi dirinya untuk melaksanakan pekerjaannya dan kepuasan kerja diri meningkat. Bagian pengembangan dan pengarahan organisasi diawali dengan memberi motivasi, karena para pimpinan tidak mampu menggerakkan kecuali kesiapan dirinya atau termotivasi agar bersedia mengikuti keinginannya (Soebagio Admodiwirio, 2001 : 145).

George R. Terry menjelaskan dalam fungsi manajemen itu adanya planning, kemudian organizing, dan actuating, serta controlling (George R Terry, 2013 : 15). Actuating merupakan penggerakan peserta atau anggota kelompok dengan sebegitu rupa sehingga mereka berusaha dan berkeinginan untuk mencapai berbagai sasaran usaha yang dikehendaki. Artinya, perencanaan laksana penggerakan dan garis start yaitu bergeraknya mobil ke arah tujuan yang ingin diperoleh berbentuk garis finish, garis finish ini tidak akan dicapai tanpa wujudnya gerak mobil. Pemahaman tentang penggerakan telah dikembangkan menjadi 3 (tiga) pendekatan: Pertama, Pendekatan Psikologis. Pendekatan tersebut didasarkan terhadap asumsi umum bahwa perilaku seseorang itu diputuskan dalam bagiannya oleh suatu struktur kepribadian unik. Itulah yang merupakan keistimewaan pribadi seseorang, sesuatu aktivitas yang signifikan dari perilaku kepemimpinannya sebagaimana yang diinginkan serta yang dikerjakan oleh seorang pemimpin.

Kedua, pendekatan sosiologis. Pendekatan yang menitikberatkan pada kelompok. Kelompok ini yang menjadi faktor penentu serta dalam 
menentukan kriteria pemimpin. Perasaan kohesif atau keterikatan di antara tingkat kepuasan anggota kelompoknya dengan anggota kelompok itu sendiri menjadi dua dimensi yang memiliki korelasi yang sangat tinggi dengan kesesuaian seorang pemimpin. Pendekatan sosiologis mewujudkan konsep pemimpin yang mendukung beragam faktor potensi, serta permissive (kebebasan) pendidikan pemimpin. Pada dasarnya pendekatan sosiologi ini bersifat situasional (Soebagio Admodiwirio, $2001:$ 12).

Ketiga, pendekatan perilaku. Pendekatan perilaku memfokuskan kepada pribadi dan situasi. Perilaku itu tidaklah berarti bisa diberlakukan pada segala situasi, namun ada kesempatan bahwa perilaku itu bisa dilakukan pada situasi yang lain. Para pakar pendekatan perilaku, kemudian mengembangkan beberapa teori tentang perilaku pemimpin:

1) Teori satu faktor

Menunjukkan bahwa tingkah laku pemimpin mampu dijelaskan sepajang satu dimensi semenjak yang berpusat kepada bawahan sampai kepada yang berpusat dengan produksi. Dimensi yang tertuju pada bawahan menciptakan apa yang disebut dengan gaya kepemimpinan. Gaya kepemimpinan ini berpusat kepada bawahan maupun kinerja itu tidaklah suatu dimensi yang bermula dari bawahan serta berakhir pada kinerja, melainkan merupakan dimensi yang saling berpegangan dari perilaku pemimpin.

2) Teori dua faktor

Teori ini terbagi dua, yaitu pertama, struktur inisasi. Dimensi ini mengarah kepada perilaku pemimpin yang tertuju atau berorientasi tugas, mengabdikan hubungan dengan bawahan dalam rangka mengembangkan pola organisasi, metode dan prosedur, serta alur komunikasi yang terjaga. Kedua, konsiderasi. Dimensi ini mengarah kepada persahabatan, saling percaya menghargai, mempercayai, serta adanya hubungan harmonis dan hangat antara kelompok dengan pimpinan dalam kelompoknya. Sering pula kedua kutub atau pola tersebut disebut dengan oreintasi manusia dan oreintasi tugas. 


\section{d. Controlling Diri Guru RA Berprestasi}

Pengawasan atau controlling diri yang juga sering disebut dengan pengendalian diri yaitu beberpa fungsi manajemen yang berbentuk mengadakan koreksi sehingga hal yang sedang dikerjakan oleh dirinya mampu diarahkan kearah yang sesuai dengan maksud tercapainya tujuan yang ditetapkan sejak awal (M. Manullang, 2005 : 23). James A. F. Stoner, memberikan pengertian bahwa pengawasan merupakan proses guna menetapkan bahwa pekerjaan sebenarnya cocok dengan kegiatan yang direncanakan (Soebagio Admodiwirio, 2001 : 12).

Control (pengawasan) diri berarti juga sebagai pengarahan atau perintah yang sesungguhnya, namun karena ditetapkan dalam peristilahan manajemen, control yang berarti memeriksa kemajuan penerapan apakah sesuai atau belum dengan rencana. Bila prestasinya mencukupi perihal apa yang diperlukan guna mencapai sasaran, serta yang bersangkutan tentu mengoreksinya (Ernest Dale, 1986 : 10). Menurut Hani Handoko pengawasan adalah menjadi proses berguna (menjamin) bahwa berbagai tujuan manajemen dan organisasi terwujud (T Hani Handoko, 2012 : 359). Sementara Panglaykim, menurutnya pengawasan yaitu menseleksi standar, pemeriksaan, titik strategis, memberikan laporan yang lalu serta mengambil tindakan.

Pengawasan diri yang dilakukan oleh guru RA berprestasi dengan cara mengevaluasi diri menurut Anton Ariyadi dalam pernyataannya sebagai berikut:

"Menjadi juara harapan 1 guru RA berprestasi menjadikan acuan bagi saya untuk lebih meningkatkan kinerja terutama dalam mengajar. Tentu evaluasi saya lakukan dengan melihat output yang saya terima juga dari apa-apa yang telah saya ajarkan. Apakah anak-anak nyaman dan senang saat saya ajar, seberapa kemampuan mereka dalam menyerap. Begitu juga saat berinteraksi dengan guru yang lain, tidak ada perubahan baik sebelum dan sesudah menjadi guru berprestasi, Justru malah menambah motivasi untuk memaksimalkan kemampuan dengan terus belajar dan menggali informasi serta inovasi dalam mengajar"(wawancara dengan Anton ariyadi, 2018).

Berbagai argumen yang telah terungkap di sini bisa disimpulkan bahwa pengawasan diri yaitu proses untuk menentukan, mewujudkan 
laporan yang lalu, menyeleksi standard, memeriksa kemajuan, mengambil tindakan, serta menjamin tujuan diri. Sedang pengawasan pendidikan terkait hal ini ialah sebuah proses pengamatan yang bertujuan mengawasi pelaksanaan suatu program pendidikan. Baik hasilnya maupun kegiatannya semenjak permulaan hingga penutupan dengan cara mengumpulkan data-data secara terus menerus. Sehingga didapat sebuah bahan yang sesuai untuk diwujudkan dasar bagi proses perbaikan dan evaluasi yang prioritas, kelak bilamana diperlukan (Kamal Muhammad, 1994 : 163).

Sistem pengawasan yang dipakai akan mempersembahkan banyak bahan yang sangat bermanfaat untuk mendapatkan fakta bagaimana suatu proses pengawasan dilaksanakan, dan sistem pengawasan itu terlaksana, untuk membimbing ataukah semata-mata hanya alat untuk membuatbuat kelemahan atau kesalahan orang. Pengawasan itu membina kreatifitas dan daya kreasi orang atau untuk menakut-nakuti; melihat pengawasan itu menjadi faktor menduga peningkatan produktivitas, atau bahkan menghalangi produktifitas. Sehingga untuk mengontrol diri dan mengevaluasi diri sebagai guru RA berprestasi, dengan teknik bertanya pada teman sejawat dan menerima masukannya (wawancara dengan Rufiyati Ambar Ningrum, 2018).

\section{Pengaruh Manajemen Diri Guru dengan Kinerja Guru RA Berprestasi}

Setiap diri pribadi guru RA berprestasi yang diberi kepercayaan atau tugas untuk mengajar pada suatu lembaga satuan pendidikan RA, diharapkan mampu serta bisa memperlihatkan kinerja yang optimal, memuaskan dan memberikan masukan serta konstribusi yang tinggi terhadap perolehan tujuan satuan pendidikan tersebut. Pada akhirnya pengaruh pengembangan diri dan kinerja yang saya lakukan ialah bisa memberikan kekuatan dan menghasilkan etos kerja yang disebut dengan kerja keras, kerja cerdas serta kerja ikhlas yang bisa menumbuhkan perilaku positif, produktif dan kontributif (wawancara dengan Rina Wahyuni, 2018).

Anton Ariyadi menyatakan bahwa: "Pengembangan diri saya dengan kinerja yang telah saya lakukan itu berpengaruh agar lebih menghargai pekerja, lebih semangat dalam bekerja dan menjadi motivasi ketika saya 
sedang down" (wawancara dengan Anton Ariyadi, 2018). Selanjutnya pengaruh manajemen diri dengan kinerja itu: "sangat menunjang kinerja saya, karena dengan pengembangan diri, saya makin tahu dan faham tentang apa yang harus saya lakukan" (wawancara dengan Sri Ngadiyati, 2018). Demikian juga diungkapkan oleh Estri Ritah Indriwati bahwa: "Pengaruhnya tambah percaya diri dan bersemangat untuk melangkah serta melakukan sesuatu hal demi kemajuan lembaga" (Estri Ritah Indriwati, 2018).

Guru merupakan sumber daya sangat penting dalam sebuah proses belajar mengajar di sekolah. Sebuah lembaga pendidikan bisa dikatakan berwibawa, bertanggung jawab, dan memiliki peranan aktif jika di dalamnya tersedia tenaga-tenaga kependidikan. Khususnya tenaga pendidikan yang mempunyai profesional dibidangnya, rasa tanggung jawab tinggi, serta mempunyai lekatan Akhlak atau norma-norma moral untuk bisa diakui sebagai guru berwajah serta berwibawa. Jabatan guru menjadi sebuah profesi meminta keahlian dan keterampilan khususnya pada aspek pendidikan atau pengajaran. Jabatan guru adalah suatu jabatan profesional.

Guru profesional tentu mempunyai ketrampilan dan pengetahuan yang langsung menyentuh masalah inti pendidikan, yaitu pengetahuan maupun ketrampilan perihal cara-cara menimbulkan dan mengarahkan proses pertumbuhan yang terbentuk dalam diri pribadi anak didik yang sedang mengalami proses pendidikan. Sebagai seorang guru tentunya memiliki sikap pengabdian dan loyalitas serta tanggung jawab terhadap profesinya. Sebab di bidang ini bersifat dinamis, bergerak terus mencari pengetahuan dan pengalaman agar semakin lama semakin ideal dan sempurna. Jika kesemuanya itu dimiliki oleh para guru, maka dengan sendirinya akan didapat citra baik terhadap profesinya tersebut (A Rahani, Abu Ahmadi, 1991:104).

Sardiman A. M. mengemukakan secara singkat bahwa seorang guru selain mempunyai kemampuan profesional, guru harus mempunyai kapasitas intelektual yang memadahi, memiliki edukasi sosial yang tinggi serta memiliki kematangan dan kedewasaan pada dirinya. Sehingga dapat memenuhi fungsinya selaku pendidik bangsa, dan guru di sekolah serta pimpinan di masyarakat (Sardiman, 2011:127). 
Beberapa ciri guru yang mampu menghambat cita-cita pada pendidikan tingkat nasional di antaranya: hipokrit (orang yang suka berpur-pura), enggan dan segan bertanggung jawab atas perbuatannya. Kondisi tersebut semestinya ilmu pengetahuan, seni dan teknologi diberdayakan untuk mempengaruhi sikap dan pola guru berprestasi (Sudarwan Danim, 2010 : 91). Kinerja guru menjadi maksimal, bilamana digabungkan atau diintegrasikan dengan berbagai komponen sekolah, baik selaku kepala atau pimpinan sekolah, guru, karyawan, iklim sekolah, maupun anak didik sebagaimana diuraikan oleh Pidarta (Made Pidarta, 2011:176). Beberapa faktor yang bisa memengaruhi kinerja guru untuk menjalankan tugasnya yang meliputi: a) Kepemimpinan terhadap kepala sekolah, b) Kondisi atau iklim sekolah, c) Harapan atau citacita, d) Keyakinan personalia sekolah. Dengan faktor tersebut terlihat bahwa efektivitas kepemimpinan dari kepala atau pimpinan sekolah, hal ini berupa manajemen kepala sekolah, akan berperan aktif dalam menentukan buruk dan baiknya kinerja guru.

Di antara aspek manajemen kepala sekolah atau kepemimpinannya yaitu pemberdayaan terhadap kinerja guru. Proses ini, bertujuan memberdayakan tenaga kependidikan dengan efektif efisien memperoleh hasil yang maksimal, tetapi tetap dalam situasi menyenangkan. Sehubungan dengan tujuan tersebut, fungsi manajemen sumber daya personalia atau guru, yang wajib dilakukan pimpinan yaitu menarik, mengembangkan, memotivasi, menggaji, personil guna meraih tujuan, membantu anggota untuk mencapai standar perilaku dan posisi, mengoptimalkan peningkatan karier tenaga kependidikan, juga menyelaraskan tujuan organisasi dan individu (Hadari Nawawi,1996 : 69).

Oleh sebab itu, semakin baik usaha kepala sekolah dalam mengembangkan sumber daya guru di sekolah, di antaranya guru, maka akan semakin baik lah kualitas guru tersebut. Kualitas guru baik, maka akan meningkatlah kinerja guru. Sebaliknya, semakin jelek usaha kepala sekolah dalam menumbuhkan sumber daya guru di sekolah, maka semakin jelek pula kualitas guru tersebut. Kualitas guru jelek, maka akan rendah kinerja guru.

Kinerja menjadikan fungsi dari motivasi maupun kemampuan. Untuk menyempurnakan tugas serta pekerjaan seorang guru RA berprestasi sepatutnya memiliki derajat tingkat kemampuan dan kesediaan tertentu. 
Keterampilan dan kesediaan diri guru RA berprestasi tidaklah cukup produktif maupun efektif untuk melakukan suatu hal tanpa pengertian yang baku dan jelas tentang apa yang akan dilakukan tersebut, dan bagaimana melaksanakannya. Kinerja menjadi perilaku konkrit yang ditampilkan setiap guru RA berprestasi sebagai produk kinerja yang ditorehkan oleh pengajar yang sesuai dengan fungsinya dalam satuan pendidikan.

a. Faktor-faktor Mempengaruhi Manajemen Diri Guru RA Berprestasi

Sesuai dengan penjelasan Anton Ariyadi bahwa: "Faktor lingkungan baik keluarga, teman kerja dan sahabat yang mempengaruhi untuk keinginan saya meraih impian, serta tak ketinggalan dorongan yang kuat dari persatuan guru RA yang terjaring dalam wadah ikatan guru RA baik tingkat cabang kabupaten maupun tingkat gugus kecamatan Depok" (wawancara dengan Anton Ariyadi, 2018). Pernyataan tersebut turut serta diamini oleh ibu Estri Ritah Indriwati bahwa yang mempengaruhi manajemen diri saya adalah: "Faktor keluarga, serta teman selembaga yayasan masyithoh serta khususnya RA tempat saya mengajar" (wawancara dengan Estri Ritah Indriwati, 2018). Sedangkan berbagai faktor yang mempengaruhi terhadap pengembangan diri saya ialah faktor lingkungan, ada 2 intern dan ekstern. Intern dari orang-orang paling dekat, suami, ayah, ibu, saudara. Kemudian ekstern dari masyarakat sekitar rumah, faktor pendidikan, serta faktor pertolongan dari Allāh SWT (wawancara dengan Rina Wahyuni, 2018).

Banyak faktor yang mampu mempengaruhi manajemen diri, antara lain yaitu faktor lingkungan seperti dikemukakan Prijosaksono faktor penting yang dapat mempengaruhi manajemen diri yaitu lingkungan. Lingkungan sosial yang menyenangkan, respon atau sikap dari lingkungan akan membentuk sikap terhadap diri seorang (self attitude). Oleh karenanya individu mendapat sikap yang sesuai dan menyenangkan dari lingkungan akan cenderung menerima dirinya, sebaliknya lingkungan dapat menjadi hambatan individu untuk meningkatkan berbagai potensi atau keahlian dalam dirinya yang bisa mempersulit dirinya untuk menerima diri walaupun individu tersebut sadar akan potensi yang dimilikinya. Hambatan-hambatan yang dihadapinya bisa 
disadari oleh gender atau jenis kelamin, rasisme, dan agama (Aribowo Prijosaksono, 2003:72).

b. Aspek-aspek Manajemen Diri Guru RA Berprestasi

Berbeda dengan aspek manajemen pada umumnya. Aspek-aspek manajemen diri guru RA berprestasi ini sebagaimana yang dinyatakan oleh Anton Ariyadi bahwa:

"Dalam pengembangan diri saya paling tidak terdapat aspek manajemen diri yang berupa augmentatif, yaitu aspek perilaku saya yang menggambarkan perbuatan meningkat dari sebelum menjadi guru RA berprestasi dengan setelah memperoleh kejuaraan kompetisi yang menempel pada predikat guru RA berprestasi pada diri saya, seperti saya lebih berhati-hati karena semua perilaku saya akan disorot sebagai teladan". Sekaligus juga terdapat aspek habituatif, yaitu perilaku saya yang menggambarkan perbuatan itu menjadi rutinitas kebiasaan yang sering saya kerjakan" (wawancara dengan Anton Ariyadi, 2018).

Namun Aribowo menjelaskan aspek manajemen diri itu berupa: pengelolaan waktu, hubungan antar manusia, serta perspektif diri dengan penjelasan sebagai berikut:

1) Pengelolaan waktu

Memanajemen waktu menjadikan hal utama dalam manajemen diri. Bagaikan kehidupan yang wajib dikelola dan dikendalikan, waktu juga mutlak dikelola serta dikendalikan dengan sebaik-baiknya agar mampu meraih sasaran sekaligus tujuan dalam pekerjaan maupun kehidupan secara efektif efisien. Selama ini penjelasan mengelola waktu hanya bisa dimaknai sebagai cara mengalokasikan waktu secara efektif efisien (Aribowo Prijosaksono, 2003:73).

2) Hubungan antar manusia

Jalinan interaksi antara manusia menjadi pilar utama dalam manajemen diri, karena individu selalu berinteraksi terhadap orang lain dalam hampir di setiap bidang kehidupan. Hubungan individu yang harmonis dan erat mampu menjadi sumber pembaruan dan kekuatan yang terus menerus. Hubungan seorang pribadi dengan orang lain efektif tidaknya sangat mempengaruhi pencapaian berbagai hal terbaik dalam sisi kehidupannya, dan dalam meningkatkan kehidupan yang lebih bermakna baik itu dalam kehidupan tempat 
tinggal atau di tempat kerja (wawancara dengan Anton Ariyadi, 2018). Strategi berhubungan langsung dengan orang lain merupakan kunci sukses utama dari sebuah kesuksesan. Dalam hidup individu manusia membutuhkan teman, kekasih, sahabat, mitra bisnis, maupun rekan kerja, juga memerlukan orang yang bisa diajak berbagi keceriaan, kesedihan, kegagalan, ketakutan, bahkan keberhasilan sekalipun. Interaksi ini membangun dan menyentuh seorang individu pada jenjang kehidupan yang terdalam.

3) Perspektif diri

Perspektif diri terwujud bila individu mampu memandang dirinya sama terhadap sesuatu yang dipandang oleh orang lain kepada dirinya sendiri. Individu seseorang yang bisa menilai dan melihat dirinya sesuai dengan apa yang dipikirkan dan yang dilihat oleh orang lain pada dirinya yang menunjukkan bahwa individu tersebut jujur dan nyata dalam menilai dirinya (Observasi, 2018). Sehingga pribadi seseorang tersebut mendapatkan kepercayaan diri yang lebih luas, pada akhirnya akan mempercepat individu tersebut dalam mengelola manajemen diri, tetapi jika individu tidak mampu melihat dirinya sesuai yang diperhatikan oleh orang lain secara tepat dan jujur dalam kenyataannya, maka akan tertuju kepada suatu kebohongan diri sendiri serta individu pribadi tersebut akan mewujudkan cermin diri yang khayal sehingga pribadi seseorang tidak dapat membenarkan kenyataan dirinya (wawancara dengan anton Ariyadi, 2018).

Aspek manajemen diri yang juga relevan dengan pendapat di atas, dikemukakan oleh Prayue, meliputi: a) Mengenali diri secara menyeluruh, b) Mengidentifikasi dengan jelas tujuan yang dicapai, c) Memahami pentingnya mencapai tujuan tersebut, d) Mengontrol dan mengelola diri (tingkah laku dan emosi), e) Melakukan evaluasi diri perihal apa yang dikerjakan dan memahami insentif-insentif yang sedang didapat dari tindakan yang dilakukan (Rengginas, 2005:78).

Selain aspek manajemen diri yang dipaparkan tersebut, ada juga aspek manajemen diri yang disampaikan oleh Gie sebagai berikut: 
a) Pendorongan diri (self motivation)

Merupakan dorongan batin yang muncul dari diri pribadi itu sendiri sehingga menimbulkan rangsangan untuk melaksanakan berbagai kegiatan agar terwujud tujuan yang ditetapkan. Dengan pendorongan diri yang kuat maka akan melahirkan minat yang besar dalam melaksanakan kegiatan yang telah ditentukan untuk mencapai tujuan.

b) Penyusunan diri atau self organization

Pengelolaan dengan sebaik-baiknya pada pikiran, waktu, tenaga, tempat, dan benda, serta berbagai sumber daya lainnya di dalam kehidupan individu sehingga tercapai efisiensi pribadi. Efisiensi pribadi merupakan pertimbangan terbaik antara setiap aktivitas hidup pribadi individu dengan hasil yang dikehendaki. Pada dasarnya penyusunan diri ialah mengurus, merencanakan, serta mengatur agar segala sesuatu dalam diri individu atau yang menyangkut diri pribadi dapat berlangsung secara tertib, lancar dan mudah.

c) Pengendalian diri atau self control

Kontrol diri merupakan perbuatan individu dalam membina hasrat untuk mendisiplinkan keinginan, mempercepat semangat, membersihkan keseganan, dan mencurahkan tenaga untuk benarbenar menjalankan sesuatu yang wajib dilakukan di dalam meraih tujuan yang diinginkan.

d) Pengembangan diri atau self development

Hal ini menjadi perilaku meningkatkan atau menyempurnakan diri pribadi dalam berbagai hal yang mencakup; kecerdasan, pikiran, watak kepribadian, rasa kemasyarakatan, dan kesehatan diri (The Liang Gie, 2000 : 77).

\section{Simpulan}

Manajemen diri guru RA berprestasi di Yogyakarta yang terdiri dari Prinsip-prinsip, fungsi, dan pengaruhnya terhadap kinerja diri guru RA berprestasi di Yogyakarta, yaitu: Pertama, Prinsip-prinsip manajemen diri yaitu 
meningkat secara efisien, efektif dalam produktivitas kerja yang berupa: pemilihan pekerjaan, metode kerja, prosedur kerja, pengembangan keahlian, menetapkan batas-batas tugas, menyediakan dan membuat spesifikasi kegiatan, melaksanakan pendidikan atau latihan, serta menjalankan sistem dan besarnya balasan.

Kedua, Fungsi manajemen diri guru RA berprestasi di Yogyakarta, yaitu untuk menumbuhkan karakter dan kompetensi diri berubah lebih baik dan menjadi pembiasaan dalam kehidupan sehari-hari. Adapun ruang lingkupnya meliputi: 1) Planning (Perencanaan) diri, Sebagai guru RA berprestasi dalam merencanakan kegiatan rutinitas yang berhubungan dengan pengembangan diri disamping persiapan mengajar juga terprogram secara periodik keikutsertaannya dalam forum-forum kajian melalui IGRA maupun KKG yang diselenggarakan tiap bulan, menyaksikan video-video inspiratif di YouTube, aktif dalam setiap kegiatan pelatihan dan workshop keRAnan. 2) Organizing diri, mengarah pada kegiatan pengembangan diri guru RA berprestasi melalui pertemuan IGRA dan KKG setiap bulan,kajian setiap jumat sore di RA, setiap semester Guru RA berprestasi selalu mengagendakan untuk merevisi buku atau lembar kerja anak di RA. 3) Actuating diri atau motivating (menggerakkan) diri, langkah yang ditempuh dengan mengatur agenda supaya pada waktu-waktu yang telah ditentukan tersebut bisa diikuti secara optimal dan baik. 4) Controlling diri dengan melihat kritik atau masukan yang membangun baik dari peserta didik, teman guru sejawat, atasan dan bahkan tokoh masyarakat demi kemajuan individunya, semuanya menjadi motivasi untuk pengembangan diri agar lebih sempurna dan barokah. Ketiga, pengaruh pengembangan diri dan kinerja guru RA berprestasi di Yogyakarta mampu memberikan kekuatan dan menghasilkan etos kerja yang disebut dengan kerja keras, kerja cerdas serta kerja ikhlas yang bisa menumbuhkan perilaku positif, produktif, maupun kontributif. Sehingga lebih menghargai pekerja, lebih semangat dalam bekerja dan menjadi motivasi ketika yang sedang down. 


\section{Daftar Pustaka}

A.M., Sardiman. 2011. Interaksi dan Motivasi Belajar Mengajar. Jakarta: Raja Grafindo Persada.

Ahmadi, Abu., A. Rahani, HM. 1991. Pedoman Penyelenggaraan Administrasi Pendidikan Sekolah. Jakarta: Bumi Aksara

Atmodiwirio, Soebagio. 2001. Manajemen Pendidikan Indonesia. Jakarta: Ardadizya Jaya.

D.R.P., Rengginas. 2005. Peran Manajemen Diri dan Kematangan Emosi dengan Pengambilan Keputusan. Yogyakarta: Fakultas Sekolah Pascasarjana Fakultas Psikologi UGM.

Dale, Ernest L.C., Michelon. 1986. Metode-metode Managemen Moderen. Jambi: Andalas Putra.

Danim, Sudarwan. 2010. Profesionalisasi dan Etika Profesi Guru. Bandung: Alfabeta.

Fattah, Nanang. 2000. Landasan Manajemen Pendidikan. Bandung: Remaja Rosdakarya.

Gie, The Liang. 2000. Cara Belajar Yang Baik Bagi Mahasiswa.. Yogyakarta: Gadjah Mada University Perss.

Handoko, T. Hani. 2012. Manajemen. Yogyakarta: BPFE.

Isa, Kamal Muhammad. 1994. Manajemen Pendidikan Islam. Jakarta: Fikahati Aneska.

Kadarman., Jusuf Udaya, 1995. Pengantar Ilmu Manajemen. Jakarta: Gramedia Pustaka Utama.

Kementerian Agama RI. 2017. Petunjuk Pelaksanaan Kompetensi Guru dan Tenaga Kependidikan Madrasah berprestasi Tahun 2017. Direktorat Guru dan Tenaga Kependidikan Madrasah, Direktorat Jenderal Pendidikan Islam.

Manullang, M. 2005. Dasar-dasar Manajemen. Yogyakarta: Gadjah Mada Press.

Muchtarom, Zaini. 1997. Dasar-dasar Manajemen Dakwah. Yogyakarta: Al-Amin dan Ikfa.

Nawawi, Hadari. 1996. Administrasi Pendidikan. Jakarta: Gunung Agung.

Pidarta, Made. 2011. Manajemen Pendidikan Indonesia. Jakarta: Rineka Cipta.

Prijosaksono, Aribowo. 2003. Self Management Series. Jakarta: Gramedia.

Saefullah, U. 2014. Manajemen Pendidikan Islam. Bandung; Pustaka Setia. 
Fu'ad

Siagian, Sondang P. 2014. Manajemen Sumber Daya Manusia. Jakarta: Bumi Aksara.

Soedjadi, F.X. 1995. $O \& M$ (Organization and methods) Penunjang Keberhasilan Proses Manajemen. Jakarta: Haji Masgung.

Stoner, James A. F. 1996. Manajemen. Jakarta: Prenhallindo.

Terry, George R. 2013. Prinsip-prinsip Manajemen. Jakarta: Bumi Aksara.

Tim Penyusun Kamus Pusat Pembinaan Pengembangan Bahasa. 2006. Kamus Besar Bahasa Indonesia. Jakarta: Balai Pustaka.

Wawancara dengan Anton Ariyadi, S.Si. guru berprestasi juara harapan I tingkat wilayah DIY tahun 2017 (Gupres 4), pengalaman mengajar selama 5 tahun dari RA Baitur Rahmah Jl. Sawitsari A-15 Gang Anggrek Condongcatur Depok Sleman, pada tanggal 16 Maret 2018.

Wawancara dengan Estri Ritah Indriwati (Gupres 2), pada 24 Juni 2018.

Wawancara dengan Rina Wahyuni (Gupres 5), pada 28 Juni 2018.

Wawancara dengan Rufiyati Ambar Ningrum (Gupres 3), pada 25 Juni 2018.

Wawancara pada hari selasa 8 Januari 2018 dengan guru berprestasi (Gupres 1), bu Sri Ngadiyati, S.Pd.AUD yang meraih juara 2 tingkat nasional yang ditetapkan di Jakarta pada 24 Nopember 2017.

Winardi. 2000. Asas-asas Manajemen. Bandung: Mandar Maju.

Wirojoedo, Soebijanto.1985. Teori Perencanaan Pendidikan. Yogyakarta: Liberty. 